\title{
Aplikasi Augmented Reality (AR) Sebagai Media Pembelajaran Siklus Embrio Manusia Berbasis Android
}

\author{
Safar ${ }^{1)}$, Jaka Permadi ${ }^{2}$, Hendrik Setyo Utomo ${ }^{3)}$ \\ 1)23) Jurusan Teknik Informatika, Politeknik Negeri Tanah Laut \\ Email : ${ }^{1)}$ farsafar.safar@gmail.com, ${ }^{2}$ jakapermadi.88@politala.ac.id, \\ 3) hendrik.tomo@politala.ac.id
}

\begin{abstract}
Abstrak
Augmented Reality (AR) menggabungkan benda nyata dan virtual yang menghasilkan obyek 3D yang akan ditampilkan pada layar. Teknologi AR pada perangkat mobile (telepon genggam dan tablet) dapat diterapkan untuk media pembelajaran. Khususnya pada Android yang memiliki pengguna yang sangat banyak dari kalangan pelajar di Indonesia. Penggunaan perangkat mobile sendiri di kalangan pelajar masih belum maksimal, karena hanya digunakan untuk komunikasi, media sosial dan bermain game. Tujuan dari dibangunnya aplikasi AR sebagai media pembelajaran siklus embrio manusia berbasis Android adalah untuk menciptakan suatu lingkungan pembelajaran yang lebih interaktif. Melalui media ini pelajar dapat berinteraksi langsung dengan obyek dunia maya sehingga pelajar dapat belajar dengan lebih menyenangkan. Aplikasi yang dibangun menampilkan objek dan video secara virtual 3D dalam sebuah penanda (marker) sebagai alat peraga gambar yang terdapat pada buku ajar siswa. Marker yang dideteksi oleh kamera akan menampilkan model 3D di layar perangkat Android secara real time dan dapat mengeluarkan suara. Aplikasi dibangun dengan menggunakan Blender, Unity dan Vuforia.
\end{abstract}

Kata kunci: Augmented Reality, aplikasi media pembelajaran, Android

\section{Abstract}

Augmented Reality (AR) combining real things and virtual things into 3D's objects that are appeared on a display screen. AR technology in mobile (smartphones and tablets) can applied for learning media. Specially for Android that have many users from students in Indonesia. The used of mobile among students is still not optimal, because the most of them only use it for communication, social media and playing games. The purpose of development AR based Android for learning media of human embrio cycles is to create a learning environment that is more interactively. From this media the students can interacting directly with cyber objects so that they can learn delightly. The development application performs 3D's objects and videos virtually from markers that is described as pictures in student's textbooks. Application will detect markers and then displaying 3D's models in the screen of the mobile real time and it can performs sounds. The apllication is developed by some softwares like Blender, Unity and Vuforia.

Keywords: Augmented Reality, application of learning media, Android

\section{PENDAHULUAN}

Augmented Reality atau yang sering disebut dengan AR diperkenalkan pertama kali oleh Morton Heiling di sekitar tahun 1950 (Chowanda, 2011). Teknologi AR menggabungkan obyek dunia maya ke dalam lingkungan nyata melalui obyek nyata tiga dimensi. Cara kerja AR berdasarkan pada deteksi citra atau yang biasa disebut marker. Kamera pada perangkat mobile menangkap marker yang telah dicetak dan kemudian menampilkannya dalam bentuk objek 3D pada layar perangkat tersebut. Teknologi AR sendiri sudah diaplikasikan dalam berbagai macam bidang, termasuk dalam bidang pendidikan. Hal ini juga memberikan dampak positif terhadap perkembangan di bidang media pembelajaran. Dengan adanya AR, media pembelajaran dapat dirancang dengan lebih atraktif dan inovatif.

Khususnya pada Android yang memiliki pengguna yang sangat banyak dari kalangan pelajar di Indonesia. Penggunaan perangkat mobile sendiri di kalangan pelajar masih belum maksimal, karena hanya digunakan untuk komunikasi, media sosial dan bermain game. Seharusnya penggunaan Android tersebut dapat lebih dimaksimalkan untuk kegiatan-kegiatan yang lebih bermanfaat, seperti menjadi tempat belajar yang lebih interaktif dan menarik. Berdasarkan wawancara yang penulis lakukan dengan beberapa pelajar SMP di Kecamatan Pelaihari, diketahui bahwa media belajar di sekolah hanya menggunakan buku dan poster. 
Pengajaran yang dilakukan oleh guru juga menggunakan metode konvensional seperti berceramah dan menjelaskan menggunakan buku pelajaran. Pengajaran seperti ini membuat responden bosan dalam kegiatan pengajaran.

Berdasarkan hal ini penulis mengangkat penelitian dengan membangun aplikasi AR untuk media pembelajaran berbasis Android. Studi kasus yang penulis angkat adalah mata pelajaran biologi, yaitu siklus embrio manusia. Tujuannya adalah untuk membangun aplikasi media pembelajaran interaktif dengan memanfaatkan teknologi AR berbasis Android yang diharapkan dapat menjadikan proses belajar mengajar lebih interaktif dan menarik.

\section{TINJAUAN PUSTAKA}

Augmented Reality (AR) adalah suatu lingkungan yang memasukkan obyek 3D ke dalam lingkungan nyata berupa penanda (marker). AR mengizinkan penggunanya untuk berinteraksi secara realtime (Gorbala dan Hariadi, 2010). Penggunaan AR saat ini telah melebar ke berbagai aspek kehidupan. Rifa'i dkk (2014) menerapkan tekknologi AR pada strategi pemasaran penjualan rumah kepada konsumen dengan membangun aplikasi katalog rumah berbasis Android. Dengan memanfaatkan teknologi AR, model rumah 3D pada katalog akan muncul di atas marker seolah-olah model rumah tersebut nyata. Pemanfaatan AR dalam media pembelajaran sudah pernah dilakukan oleh Ananda dkk (2015). Teknologi AR diterapkan dalam media pembelajaran untuk mengenal planet-planet di tata surya.

Dalam membangun aplikasi AR sendiri diperlukan beberapa software seperti Unity, Vuforia dan Blender. Unity merupakan game engine yang dibuat oleh Unity Technology. Kelebihan Unity dibanding game engine lainnya adalah kemampuan dalam membuat game cross platform, sehingga game yang dibuat dapat dimainkan di beberapa perangkat seperti smartphone dan game console (Wahan Komputer, 2014). Dengan kemampuannya ini Unity dapat digunakan untuk membuat konten
3D yang interaktif dan bersifat multiplatform (Saputra, 2014). Hal ini yang kemudian membuat Unity digunakan dalam pembangunan aplikasi AR.

Vuforia merupakan software untuk AR yang dikembangkan oleh Qualcomm. Vuforia menggunakan sumber mengenai computer vision yang fokus pada pengenalan citra (Fernando, 2013). Sedangkan Blender adalah software yang open source, ringan dan multiplatform yang digunakan untuk membuat konten multimedia khususnya obyek 3D (Ardhianto dkk, 2012).

\section{METODE PENELITIAN}

\section{Kerangka Penelitian}

1. Problem, bagaimana merancang dan membangun aplikasi AR sebagai media pembelajaran siklus embrio manusia berbasis Android.

2. Approach, merancang dan membangun sistem pembelajaran tentang siklus embrio manusia dengan menggunakan teknologi AR pada smartphone yang berbasis Android.

3. Development, perancangan sistem menggunakan DFD dan Flowchart. Software yang digunakan untuk membangun AR adalah Unity, Vuforia dan Blender. Bahasa pemrograman yang digunakan adalah Visual C\#.

4. Implementation, aplikasi AR sebagai media belajar diimplementasikan di perangkat smartphone Android, khususnya milik pelajar dan guru biologi tingkat SMP.

5. Result, aplikasi AR sebagai media pembelajaran siklus embrio manusia berbasis Android berhasil dibangun dan dapat diimplementasikan di perangkat smartphone Android.

\section{Analisis Kebutuhan Sistem}

Analisis kebutuhan sistem dilakukan setelah melakukan wawancara dengan beberapa pelajar SMP dan guru biologi SMP di Kecamatan Pelaihari. Hasil analisis kebutuhan sistem yang dilakukan adalah sebagai berikut: 
1. Aplikasi yang dibangun menampilkan obyek 3D siklus embrio manusia yaitu sperma, embrio, zigot, obyek bayi, anak-anak, remaja dan dewasa.

2. Aplikasi dapat mengeluarkan audio yang bersesuaian dengan obyek yang dimunculkan.

3. Aplikasi menampilkan objek dari suatu marker.

4. Marker ditanam dalam buku ajar yang membahas siklus embrio manusia.

5. Pada aplikasi yang dibangun, data dibatasi pada gambar sperma, mitosis, meiosis, janin, bayi dan fertilisasi.

\section{Alat Bantu Pengembangan Sistem}

Dalam pembangunan aplikasi, software dan hardware yang digunakan adalah sebagai berikut:

1. Software (perangkat lunak)
a. Visual C\#
b. Unity 3D 5.5.2
c. Vuforia SDK
d. Adobe Photoshop CS6
e. Blender
f. Microsoft Visio 2013 dalam pembuatan DFD dan Flowchart
g. Microsoft Word 2013 dalam pembuatan laporan

2. Hardware (perangkat keras)
a. Laptop Acer Aspire V5
b. Smartphone
c. Buku ajar sebagai marker

\section{RANCANGAN SISTEM}

\section{Rancangan Aliran Data}

Aliran data dirancang dengan menggunakan Data Flow Diagram (DFD). User dari aplikasi diarahkan untuk mengambil data marker oleh aplikasi, yang kemudian aplikasi akan menampilkan obyek 3D atau video berkaitan dengan data marker yang diambil. Diagram konteks dari aplikasi yang dirancang ditunjukkan pada Gambar 1 berikut.

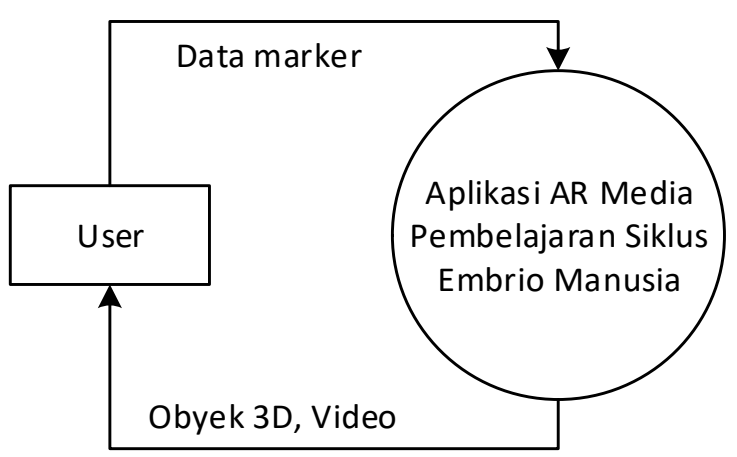

Gambar 1. Diagram konteks dari aplikasi yang dibangun

\section{Rancangan Alur Sistem}

Alur dari aplikasi yang dibangun dirancang dengan menggunakan flowchart, yang ditunjukkan pada Gambar 2.

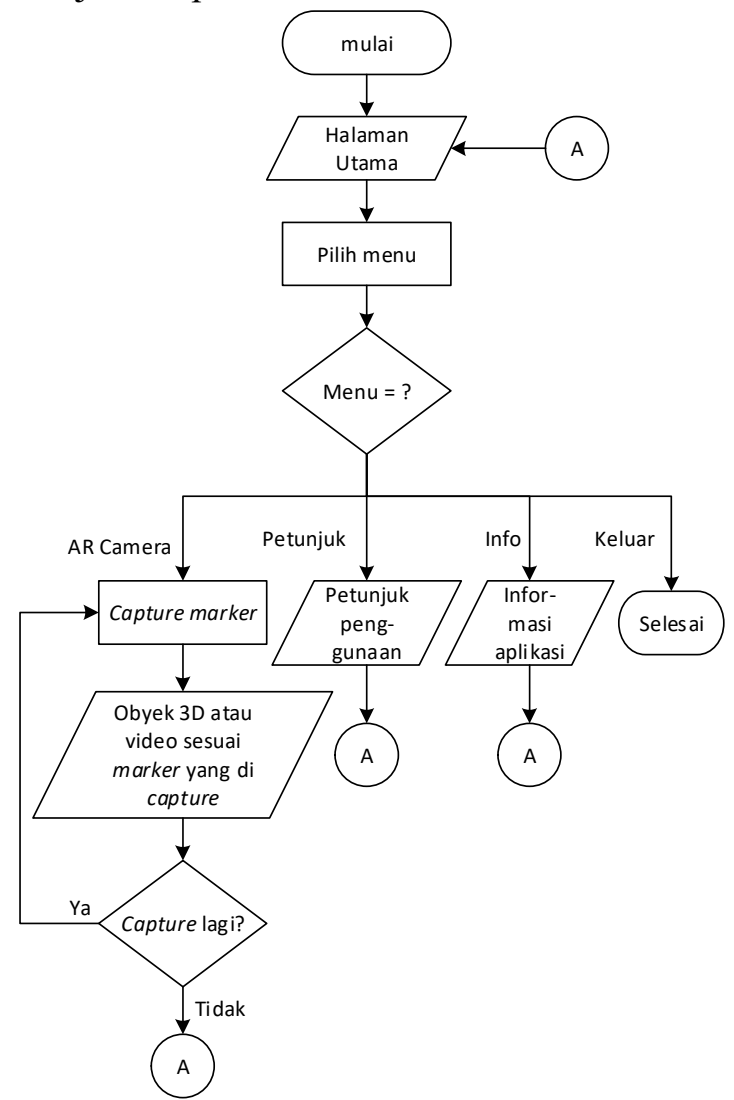

Gambar 2. Flowchart dari aplikasi yang dibangun

Ketika aplikasi diaktifkan, user diarahkan menuju halaman utama yang memiliki empat menu, yaitu AR Camera, Petunjuk, Info dan Keluar. Ketika user memilih menu AR Camera, aplikasi akan mengarahkan user untuk mengcapture marker menggunakan kamera dari smartphone yang digunakan. Kemudian aplikasi akan menampilkan obyek 3D atau 
video yang bersesuaian dengan marker yang dicapture. Setelah itu user dapat melanjutkan untuk mengcapture marker lagi atau kembali ke halaman utama. Menu Petunjuk berisikan tentang petunjuk penggunaan aplikasi, sedangkan menu Info berisikan tentang informasi developer aplikasi. Menu Keluar digunakan ketika user hendak menutup aplikasi.

\section{HASIL DAN PEMBAHASAN}

\section{Tampilan Halaman Pembuka}

Halaman pembuka adalah halaman awal dari aplikasi setelah aplikasi dijalankan. Halaman ini hanya akan muncul selama beberapa detik saja yang kemudian aplikasi akan menampilkan halaman utama. Tampilan halaman pembuka ditunjukkan pada Gambar 3.

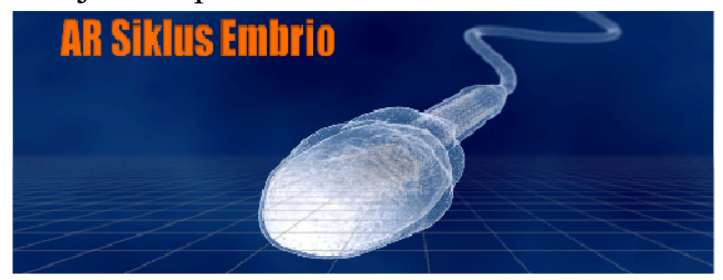

Gambar 3. Halaman pembuka

\section{Tampilan Halaman Utama}

Halaman utama muncul setelah beberapa detik dari halaman pembuka. Halaman utama menampilkan empat buah menu, yaitu menu AR Camera, menu Petunjuk, menu Info dan menu Keluar. Tampilan halaman utama dapat dilihat pada Gambar 4.

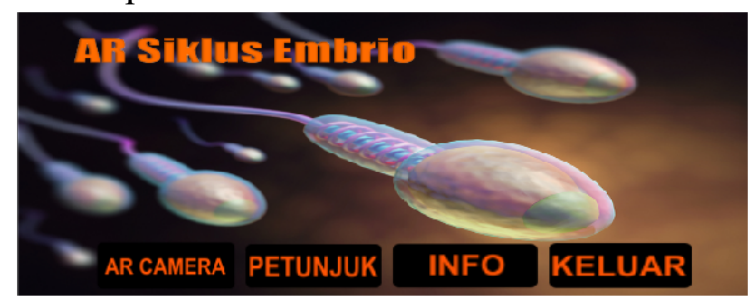

Gambar 4. Halaman utama

\section{Tampilan Halaman Petunjuk}

Halaman petunjuk akan ditampilkan ketika menu Petunjuk pada halaman utama dipilih. Halaman petunjuk menampilkan petunjuk penggunaan aplikasi pada setiap menu. Tampilan halaman petunjuk dapat dilihat pada Gambar 5.

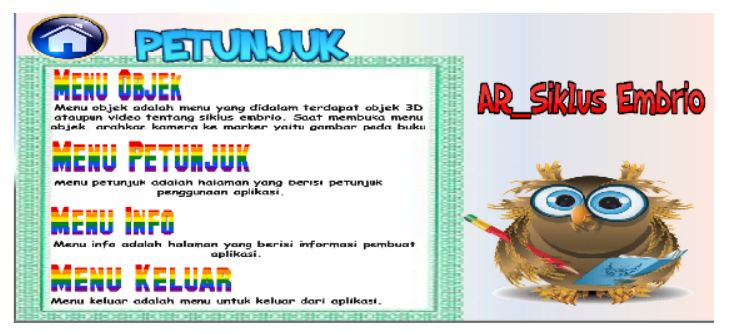

Gambar 5. Halaman petunjuk

\section{Tampilan Halaman Info}

Halaman info muncul ketika menu Info pada halaman utama dipilih. Halaman info menampilkan pembuat aplikasi beserta dosen pembimbing. Halaman info dapat dilihat pada Gambar 6.

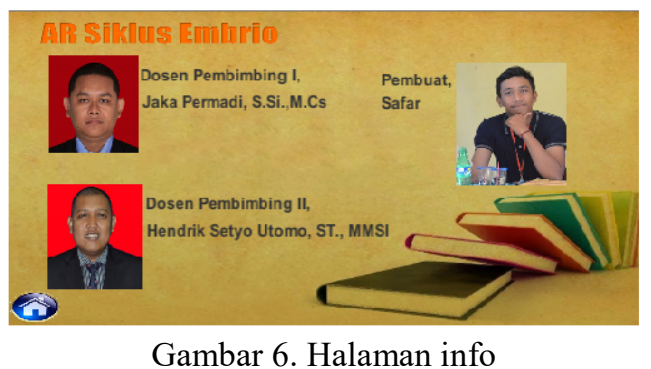

\section{Tampilan Obyek Sperma}

Setelah memilih menu AR Camera pada halaman utama dan kemudian mengarahkan kamera smartphone ke marker sperma, aplikasi AR kemudian menampilkan obyek sperma dalam 3D. Obyek tersebut dapat dirotasi oleh user sehingga user dapat mempelajari bentuk sperma dengan lebih interaktif. Selain itu audio yang menjabarkan sperma dengan lebih detail juga dapat dimunculkan. Objek sperma dapat dilihat pada Gambar 7.

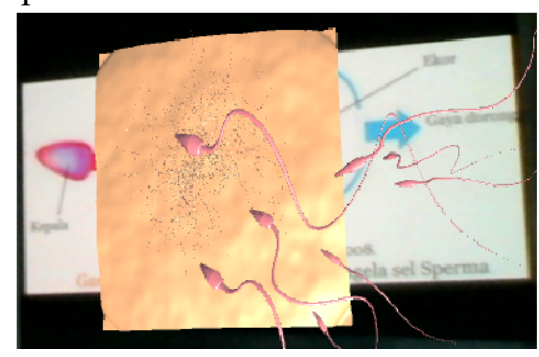

Gambar 7. Tampilan obyek sperma 3D dari aplikasi AR

\section{Tampilan Obyek Janin}

Sama seperti tampilan objek sperma, jika kamera smartphone diarahkan ke marker janin, maka aplikasi AR akan memunculkan obyek janin dalam bentuk 3D. Obyek janin tersebut juga dapat dirotasi dan diberikan fitur untuk 
memunculkan audio yang berisi tentang penjelasan janin yang lebih detail. Tampilan obyek janin dapat dilihat pada Gambar 8 .

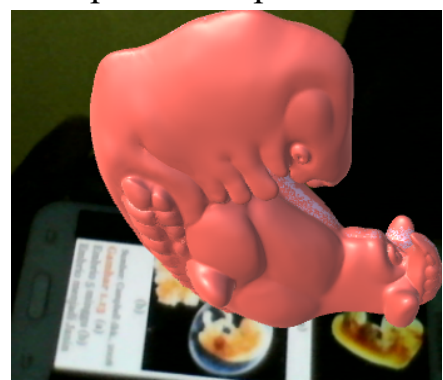

Gambar 8. Tampilan obyek janin 3D dari aplikasi AR

\section{Tampilan Obyek Bayi}

Jika kamera smartphone diarahkan ke marker bayi, maka aplikasi AR akan memunculkan obyek bayi dalam bentuk 3D. Tampilan obyek bayi dapat dilihat pada Gambar 9.

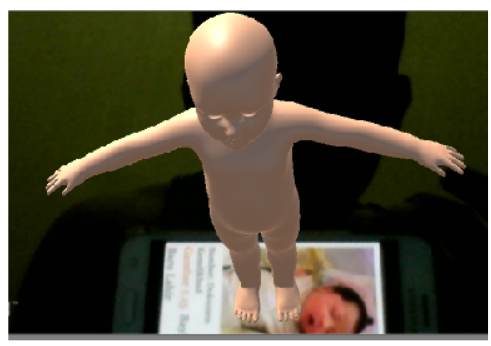

Gambar 9. Tampilan obyek bayi 3D dari aplikasi AR

\section{Tampilan Video Mitosis}

Jika kamera smartphone diarahkan ke marker proses mitosis, maka aplikasi AR akan menampilkan video proses mitosis. Dalam video proses mitosis ini dijelaskan secara rinci proses mitosis melalui sebuah animasi. Diharapkan dengan menonton video tersebut pelajar menjadi mengetahui lebih detail tentang proses mitosis daripada hanya membacanya dari buku. Tampilan video proses mitosis dapat dilihat pada Gambar 10.

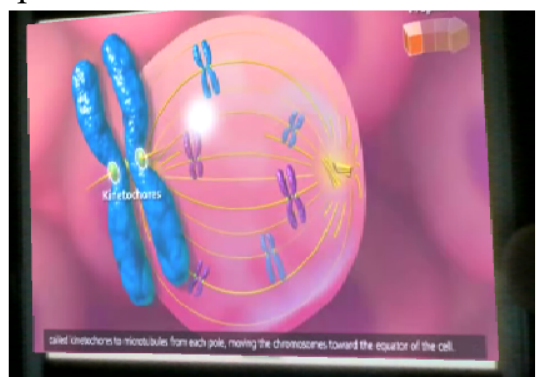

Gambar 10. Tampilan video proses mitosis dari aplikasi AR

\section{Tampilan Video Proses Meiosis}

Jika kamera smartphone diarahkan ke marker proses meiosis, maka aplikasi AR akan menampilkan video proses meiosis. Dalam video proses meiosis ini dijelaskan secara rinci proses meiosis melalui sebuah animasi. Diharapkan dengan menonton video tersebut pelajar menjadi mengetahui lebih detail tentang proses meiosis. Tampilan video proses meiosis dapat dilihat pada Gambar 11.

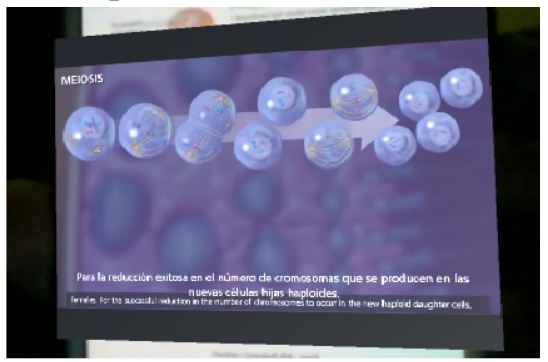

Gambar 11. Tampilan video proses meiosis dari aplikasi AR

\section{Tampilan Video Proses Fertilisasi}

Jika kamera smartphone diarahkan ke marker proses fertilisasi, maka aplikasi AR akan menampilkan video proses fertilisasi. Dalam video proses meiosis ini dijelaskan secara rinci proses fertilisasi melalui sebuah animasi. Diharapkan dengan menonton video tersebut pelajar menjadi mengetahui lebih detail tentang proses fertilisasi. Tampilan video fertilisasi meiosis dapat dilihat pada Gambar 12.

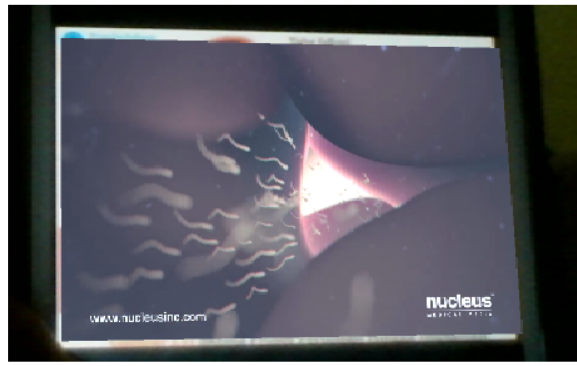

Gambar 12. Tampilan video proses fertilisasi dari aplikasi AR

\section{Pengujian Sistem}

Pada pengujian sistem menggunakan smartphone Samsung J2, dengan spesifikasi sebagai berikut:

1. Prosessor Quad-Core $1.3 \mathrm{GHz}$ Cortex-A7

2. Internal $8 \mathrm{~GB}, 1 \mathrm{~GB}$ RAM

3. OS Android 5.1.1 (Lollipop)

4. Resolusi layar 4.7 inch, 540 x 960 pixels, 16:9 ratio ( $\sim 234$ ppi density) 


\section{GPU Mali-T720}

6. Kamera utama 8 MP, Kamera depan 5 MP

Pengujian sistem dilakukan oleh dosen pembimbing yang merupakan dosen Jurusan TI Politeknik Negeri Tanah Laut, yaitu Jaka Permadi, M.Cs dan Hendrik Setyo Utomo, MMSI. Pengujian yang dilakukan adalah pengujian blackbox dengan hasil pengujian dapat dilihat pada Tabel 1 berikut.

Tabel 1. Hasil pengujian aplikasi AR siklus embrio manusia berbasis Android

\begin{tabular}{|c|c|c|c|}
\hline No & $\begin{array}{c}\text { Kasus } \\
\text { Uji }\end{array}$ & $\begin{array}{c}\text { Hasil yang } \\
\text { Diharapkan }\end{array}$ & $\begin{array}{c}\text { Hasil } \\
\text { Pengujian }\end{array}$ \\
\hline 1 & $\begin{array}{l}\text { Install } \\
\text { APK }\end{array}$ & $\begin{array}{l}\text { Aplikasi } \\
\text { terpasang pada } \\
\text { smartphone } \\
\text { Android dan } \\
\text { dapat dijalankan }\end{array}$ & Berhasil \\
\hline 2 & $\begin{array}{l}\text { Aplikasi } \\
\text { dijalankan }\end{array}$ & $\begin{array}{l}\text { Aplikasi } \\
\text { memunculkan } \\
\text { halaman } \\
\text { pembuka dan } \\
\text { kemudian } \\
\text { halaman utama }\end{array}$ & Berhasil \\
\hline 3 & $\begin{array}{l}\text { Memilih } \\
\text { menu } \\
\text { petunjuk }\end{array}$ & $\begin{array}{l}\text { Tampil halaman } \\
\text { petunjuk }\end{array}$ & Berhasil \\
\hline 4 & $\begin{array}{l}\text { Memilih } \\
\text { menu info }\end{array}$ & $\begin{array}{l}\text { Tampil halaman } \\
\text { info }\end{array}$ & Berhasil \\
\hline 5 & $\begin{array}{l}\text { Memilih } \\
\text { menu } \\
\text { keluar }\end{array}$ & $\begin{array}{l}\text { Keluar dari } \\
\text { aplikasi }\end{array}$ & Berhasil \\
\hline 6 & $\begin{array}{l}\text { Memilih } \\
\text { menu AR } \\
\text { Camera }\end{array}$ & $\begin{array}{l}\text { Muncul tampilan } \\
\text { untuk } \\
\text { menangkap } \\
\text { marker }\end{array}$ & Berhasil \\
\hline 7 & $\begin{array}{l}\text { Capture } \\
\text { marker } \\
\text { sperma }\end{array}$ & $\begin{array}{l}\text { Muncul obyek } \\
\text { sperma 3D dan } \\
\text { audio }\end{array}$ & Berhasil \\
\hline 8 & $\begin{array}{l}\text { Capture } \\
\text { marker } \\
\text { janin }\end{array}$ & $\begin{array}{l}\text { Muncul obyek } \\
\text { janin 3D dan } \\
\text { audio }\end{array}$ & Berhasil \\
\hline 9 & $\begin{array}{l}\text { Capture } \\
\text { marker } \\
\text { bayi }\end{array}$ & $\begin{array}{l}\text { Muncul obyek } \\
\text { bayi 3D }\end{array}$ & Berhasil \\
\hline 10 & $\begin{array}{l}\text { Capture } \\
\text { marker } \\
\text { mitosis }\end{array}$ & $\begin{array}{l}\text { Tampil video } \\
\text { mitosis }\end{array}$ & Berhasil \\
\hline 11 & $\begin{array}{l}\text { Capture } \\
\text { marker } \\
\text { meiosis }\end{array}$ & $\begin{array}{l}\text { Tampil video } \\
\text { meiosis }\end{array}$ & Berhasil \\
\hline 12 & $\begin{array}{l}\text { Capture } \\
\text { marker } \\
\text { fertilisasi }\end{array}$ & $\begin{array}{l}\text { Tampil video } \\
\text { fertilisasi }\end{array}$ & Berhasil \\
\hline
\end{tabular}

\section{KESIMPULAN}

1. Telah berhasil dirancang dan dibangun aplikasi AR sebagai media pembelajaran siklus embrio manusia berbasis Android.

2. Aplikasi telah diuji dan berjalan dengan baik di smartphone Samsung J2.

\section{DAFTAR PUSTAKA}

Ananda, T.A., Safriadi, N. and Sukamto, A.S., 2015. Penerapan Augmented Reality Sebagai Media Pembelajaran Mengenal Planet-Planet di Tata Surya. Jurnal Sistem dan Teknologi Informasi (JustIN), 4(1), pp.139-144.

Ardhianto, E., Hadikurniawati, W. and Winarno, E., 2012. Augmented Reality Objek 3 Dimensi dengan Perangkat Artoolkit dan Blender. Dinamik-Jurnal Teknologi Informasi, 17(2).

Chowanda, A., 2011. Perancangan Game Kartu Interaktif Berbasis Android Menggunakan Augmented Reality. ComTech: Computer, Mathematics and Engineering Applications, 2(2), pp.726-735.

Fernando, M., 2013. Membuat aplikasi android augmented reality menggunakan vuforia sdk dan unity. Surakarta: AR Online.

Gorbala, B.T. and Hariadi, M., 2010. Aplikasi Augmented Reality untuk Katalog Penjualan Rumah. Institut Sepuluh Nopember Surabaya.

Rifa'i, M., Listyorini, T. and Latubessy, A., 2014. Penerapan Teknologi Augmented Reality pada aplikasi katalog rumah berbasis android. Prosiding SNATIF, pp.267-274.

Saputra, Y.A., 2014. Implementasi Augmented Reality (AR) Pada Fosil Purbakala di Museum Geologi Bandung. Jurnal Ilmiah Komputer dan Informatika (KOMPUTA), pp.1-8.

Wahana Komputer., 2014. Mudah Membuat Game 3 Dimensi Menggunakan Unity 3D. Yogyakarta: Penerbit Andi. 